\title{
DEMONSTRATION OF A CIRCULATING ANTICOAGULANT IN PLASMA THROMBOPLASTIN ANTECEDENT DEFICIENCY
}

\author{
By AARON M. JOSEPHSON AND RUBEN LISKER \\ (From the Department of Hematologic Research, Medical Research Institute, Michael Reese \\ Hospital, Chicago, Ill.)
}

(Submitted for publication July 23, 1957; accepted September 12, 1957)

Resistance to transfusion therapy in the hereditary hemorrhagic syndromes has long been known to occur. Lawrence and Johnson (1) in 1941 demonstrated a circulating anticoagulant in a case of classical hemophilia. Numerous reviews on the subject of circulating anticoagulants have recently appeared (2-4). Richards and Spaet (5), and Lewis and Didisheim (6) have been able to produce an antibody directed against antihemophilic globulin (AHG) in animals. These studies give support to the concept of an immunologic mechanism for the production of a circulating anticoagulant in hemophilics. Resistance to transfusion in plasma thromboplastin component deficiency (PTC) has also been reported $(3,7)$.

Recently the opportunity arose to study a resistant state in a case of plasma thromboplastin antecedent deficiency (PTA). This case has previously been reported as a demonstration of the steps necessary to correct the hemorrhagic diathesis before and during surgery (8). The usual techniques for demonstration of a circulating anticoagulant were uniformly unsuccessful in this patient. A modification of the thromboplastin generation test (TGT) was used which enabled us to demonstrate the resistant state in vitro.

\section{METHODS}

Whole blood clotting time was done by the Lee-White method (9). One stage plasma prothrombin time was performed according to Quick's technique (10), and serum prothrombin time was done by a modification of Quick's method (11). The thromboplastin generation test was done as described by Biggs and Douglas (12). The search for circulating anticoagulants was performed by mixing normal and patient's blood and determining the clotting times (13) and serum prothrombin times of such mixtures (4). Plasma recalcification times of similar mixtures were also performed (3). Heparin protamine titration test was done following the technique of Allen and co-workers (14).

Case presentation. This case has previously been reported as one of a family demonstrating PTA deficiency (see Table I and Figure 1) (15). Patient I. S. is a 50 year old white female. In 1943, 1947, and 1948 she required surgery for various diseases. Each surgical episode necessitated a large number of blood transfusions for correction of operative hemorrhage. In 1955 she was examined in this department and was found to have PTA deficiency.

In August of 1956 she was again admitted to Michael Reese Hospital for removal of a stone in the cystic duct. At this time it was noted that she had a marked resistance to transfusion, and correction of her hemorrhagic diathesis came about only by the use of a modified exchange transfusion procedure. At this time demonstration of a circulating anticoagulant by the usual techniques was unrewarding (see Table II). Three months after surgery further studies were undertaken to define the state of resistance in this patient.

Special techniques. At the present time the available evidence indicates that the state of resistance in the various hereditary hemorrhagic deficiencies is most likely due to the development of an antibody to the coagulation factor which is lacking. This resistance presumably comes about because of immunization by transfusion of normal blood or plasma. This so-called antibody is usually demonstrated by the anticoagulant effect on normal blood. Some antigen-antibody reactions are demonstrable only by special techniques, one of the most common being incubation at $37^{\circ} \mathrm{C}$. We, therefore, undertook to perform the thromboplastin generation test, using mixtures of one part of the patient's reagent to nine parts of the normal reagent. Plasma recalcification times were performed in the same manner. All mixtures and individual reagents were incubated at $37^{\circ} \mathrm{C}$. for four hours. The reagents were tested to determine loss of potency and none was found. Both normal and the patient's substrates were used and no difference was found. Four hours was chosen for the incubation time because of technical reasons in doing such a large number of generation studies.

\section{RESULTS}

In the technique of plasma recalcification time, mixtures of one part patient's plasma to nine parts normal plasma were incubated at $37^{\circ} \mathrm{C}$. for four hours. At half-hourly intervals, tubes were removed and the recalcification time determined. A second series using patient's adsorbed plasma was also examined. Incubation of these mixtures 
TABLE I

Proof of PTA deficiency on basis of crossmatching experiments

\begin{tabular}{lcc}
\hline \hline \multicolumn{1}{c}{ Mixture* } & & $\begin{array}{c}\text { Serum } \\
\text { pro- } \\
\text { Clotting } \\
\text { thrombin } \\
\text { time } \\
\text { (minules) }\end{array}$ \\
(seconds)
\end{tabular}

* All addition experiments were performed by adding $0.1 \mathrm{ml}$. of the reagent to $0.9 \mathrm{ml}$. of the tested blood.

did not provide any evidence of inhibition of normal plasma. The use of a 50 per cent mixture of plasmas also showed no effect of an anticoagulant on the normal plasma. On the contrary, these

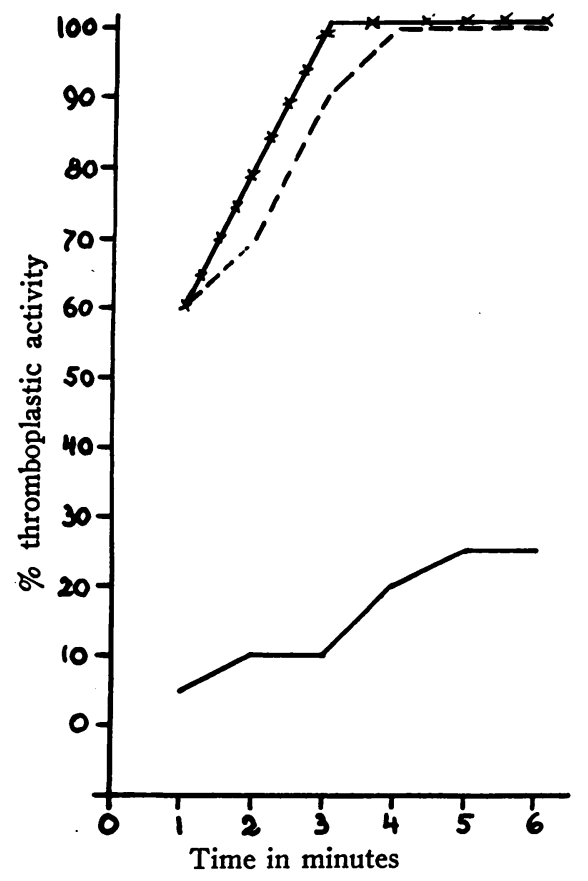

Fig. 1. Thromboplastin Generation Test

The different mixtures are represented as follows:

Patient's platelets plus patient's $\mathrm{BaSO}_{4}$ plasma plus the patient's serum.

$-\mathrm{x}-\mathrm{x}-$ Patient's platelets plus normal $\mathrm{BaSO}_{4}$ plasma plus the patient's serum.

- - - - Patient's platelets plus patient's $\mathrm{BaSO}_{4}$ plasma plus the normal serum.
TABLE II

Tests for circulating anticoagulants

\begin{tabular}{|c|c|c|}
\hline \multirow[b]{2}{*}{ Mixture } & \multicolumn{2}{|c|}{ Type of test } \\
\hline & $\begin{array}{c}\text { Clotting } \\
\text { time } \\
\text { (minutes) }\end{array}$ & $\begin{array}{l}\text { Serum } \\
\text { pro- } \\
\text { thrombin } \\
\text { time } \\
\text { (seconds) }\end{array}$ \\
\hline \multirow{2}{*}{$\begin{array}{l}1 \mathrm{ml} \text {. normal blood } \\
1 \mathrm{ml} \text { normal blood }+0.3 \mathrm{ml} . \mathrm{NaCl} \\
1 \mathrm{ml} \text {. normal blood }+0.3 \mathrm{ml} \text {. patient's } \\
\text { blood }\end{array}$} & ${ }_{10}^{9.6}$ & \\
\hline & 10 & \\
\hline \multirow{3}{*}{$\begin{array}{l}2 \mathrm{ml} . \text { normal blood } \\
2 \mathrm{ml} \text { normal blood }+0.3 \mathrm{ml} . \mathrm{NaCl} \\
2 \mathrm{ml} \text { normal blood }+0.3 \mathrm{ml} \text {. patient's } \\
\text { blood }\end{array}$} & & $\begin{array}{l}35 \\
33\end{array}$ \\
\hline & & 29 \\
\hline & $\begin{array}{l}\text { Plasma } \\
\text { recalcifi- } \\
\text { cation } \\
\text { time* } \\
\text { (seconds) }\end{array}$ & $\begin{array}{l}\text { Incubated } \dagger \\
\text { plasma } \\
\text { recalcifi- } \\
\text { cation } \\
\text { time } \\
\text { (seconds) }\end{array}$ \\
\hline \multirow{2}{*}{$\begin{array}{l}0.2 \mathrm{ml} . \text { normal plasma } \\
0.1 \mathrm{ml} \text {. normal plasma }+0.1 \mathrm{ml} \text {. } \\
\text { patient's plasma }\end{array}$} & 120 & 180 \\
\hline & 120 & 195 \\
\hline \multirow{2}{*}{$\begin{array}{l}0.2 \mathrm{ml} \text {. patient's plasma } \\
0.1 \mathrm{ml} \text {. patient's BaSO } \text { plasma }+ \\
0.1 \mathrm{ml} \text {. normal plasma }\end{array}$} & 150 & 185 \\
\hline & 125 & 190 \\
\hline
\end{tabular}

* Plasma recalcification times performed by mixing equal volumes of plasma and $0.2 \mathrm{M} \mathrm{CaCl}_{2}$.

$\dagger$ Incubation carried out at $37^{\circ} \mathrm{C}$. for four hours.

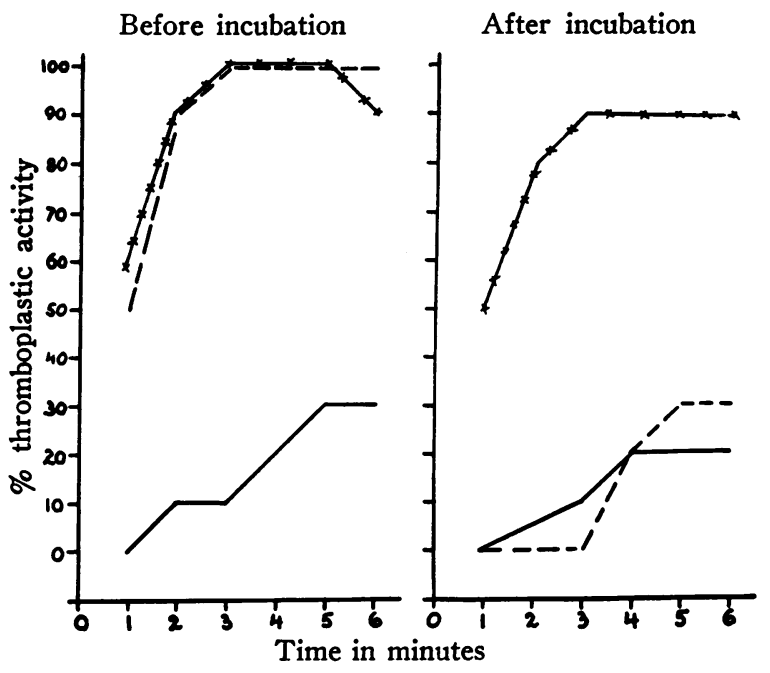

Fig. 2. Thromboplastin Generation Test Using a Mixture of Normal and the Patient's Adsorbed Plasma

The different mixtures are represented as follows:

Patient's platelets plus patient's $\mathrm{BaSO}_{4}$ plasma plus the patient's serum.

$-\mathrm{x}-\mathrm{x}-$ Patient's platelets plus normal $\mathrm{BaSO}_{4}$ plasma plus the patient's serum.

_ - - - Patient's platelets plus mixture of normal plus patient's $\mathrm{BaSO}_{4}$ plasma plus the patient's serum. 


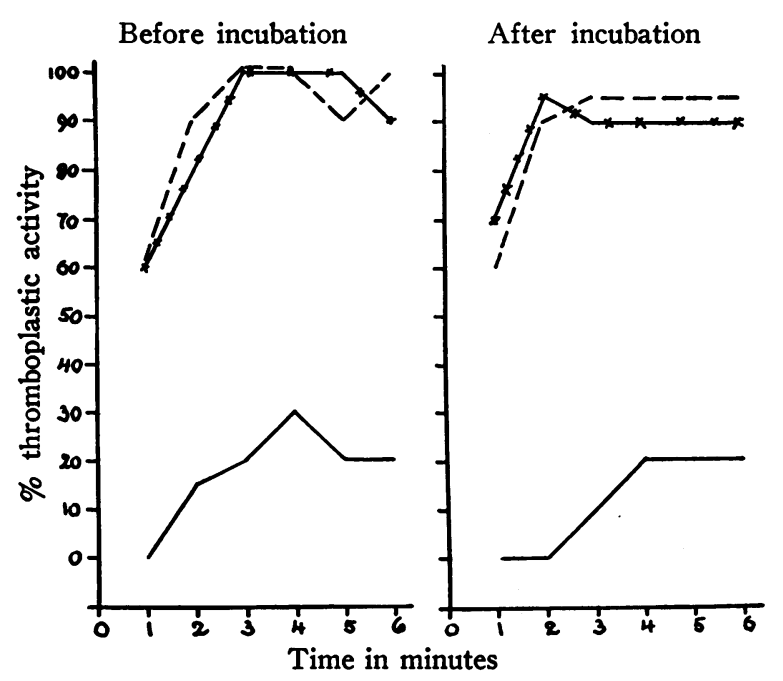

Fig. 3. Thromboplastin Generation Test Using a Mixture of Normal and the Patient's Serum

The different mixtures are represented as follows:
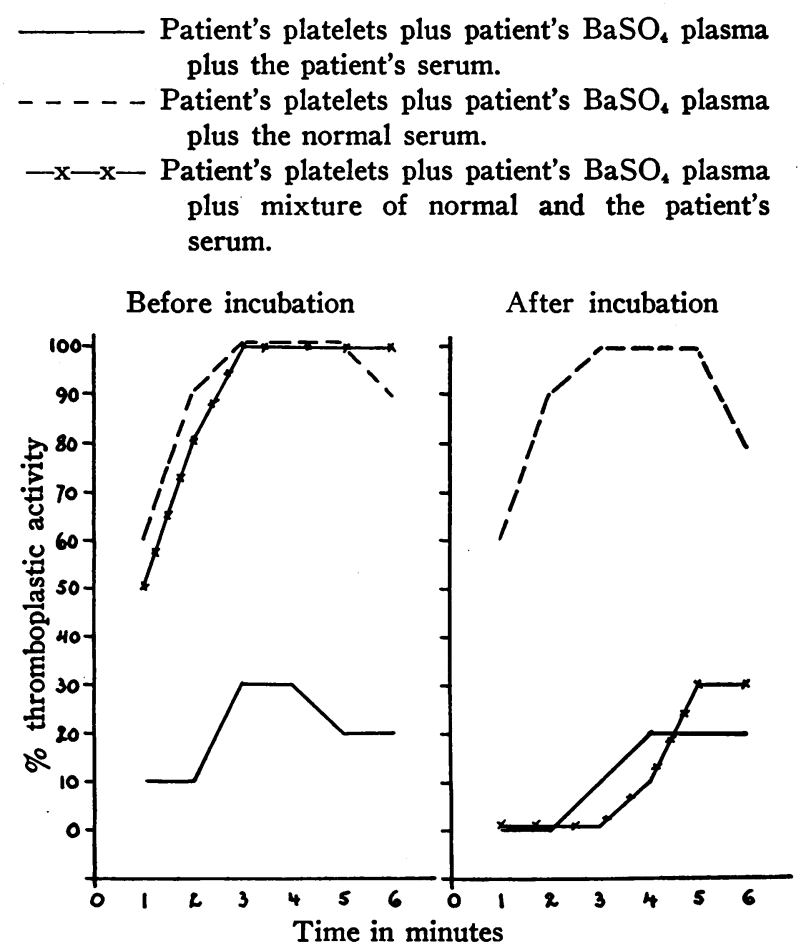

Fig. 4. Thromboplastin Generation Test Using Mixtures of Patient's Adsorbed Plasma and Normal SERUM

The different mixtures are represented as follows:

Patient's platelets plus patient's $\mathrm{BaSO}_{4}$ plasma plus the patient's serum.

- - - - Patient's platelets plus patient's $\mathrm{BaSO}_{4}$ plasma plus the normal serum.

$-\mathrm{x}-\mathrm{x}-$ Patient's platelets plus patient's $\mathrm{BaSO}$, plasma plus mixture of normal serum and the patient's $\mathrm{BaSO}_{4}$ plasma.

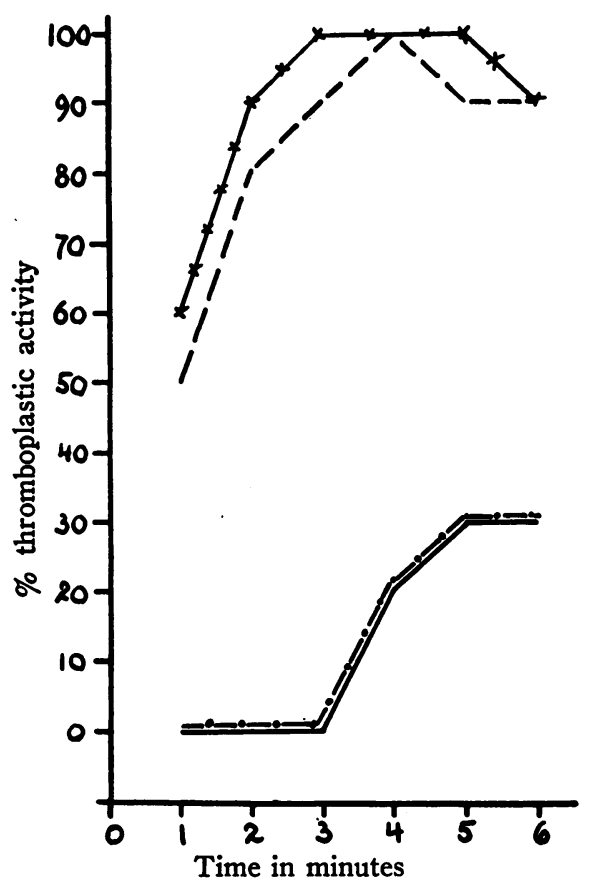

Fig. 5. Thromboplastin Generation Test Demonstrating Effect of Addition of Nonadsorbed Plasma or Serum on the Mixtures Incubated for Four Hours

The different mixtures are represented as follows:

Patient's platelets plus incubated mixture of normal and the patient's plasma plus the patient's serum.

-.- - Patient's platelets plus patient's plasma plus incubated mixture of normal serum and the patient's plasma.

- - - - Patient's platelets plus incubated mixture of normal and the patient's plasma plus the normal serum.

- $x-x-$ Patient's platelets plus normal plasma plus incubated mixture of normal serum and the patient's plasma.

tests provided evidence of correction of the patient's coagulation defect by normal plasma.

A mixture of one part patient's to nine parts normal $\mathrm{BaSO}_{4}$ plasma or normal $\mathrm{BaSO}_{4}$ plasma alone were equally effective in producing correction of the TGT (Figure 1). After four hours incubation, the mixture had lost its potency; however, the incubated non-mixed normal $\mathrm{BaSO}_{4}$ plasma was as effective as before (Figure 2).

Figure 3 demonstrates the results using mixtures of normal and the patient's serum. No loss of thromboplastic activity is evident after incubation.

Figure 4 shows that a mixture of normal serum 
and patient's adsorbed plasma resulted in a marked loss of thromboplastic activity after incubation.

Figure 5 demonstrates an experiment designed to rule out any inhibitory effect of the anticoagulant against either AHG or PTC. When the patient's and normal $\mathrm{BaSO}_{4}$ plasma were incubated for four hours, correction in the TGT could be accomplished by addition of normal serum (which does not contain AHG). This then rules out AHG inhibition. In like manner, when a four hour incubation of the patient's plasma and normal serum was tested against normal plasma, correction was again achieved indicating that PTC was not inhibited (normal adsorbed plasma does not contain PTC). Correction by addition of either the patient's plasma or serum could not be obtained.

Precipitation of the anticoagulant from the plasma was accomplished by ammonium sulfate fractionation. A 25 to 33 per cent ammonium sulfate solution produced complete removal of the anticoagulant. Zero to 20 per cent saturation removed only small amounts of the anticoagulant. Rosenthal (16) found maximal activity of the PTA substance in the 25 to 33 per cent fraction. Heating of the patient's plasma for 20 minutes at $60^{\circ}$ C. removed all traces of anticoagulant activity as did storage for three months at $4^{\circ} \mathrm{C}$.

\section{DISCUSSION}

Analysis of the data reveals that the patient under study demonstrated a primary PTA deficiency with a previously undescribed circulating anticoagulant. This anticoagulant was present only in the patient's plasma and was directed against the formation of thromboplastin. The inhibitory substance acted against a coagulation factor which is present in both serum and plasma and was neither AHG nor PTC. Previous studies revealed that our patient lacked only PTA and therefore the circulating anticoagulant was most likely directed against PTA.

These results are not entirely surprising because it is well known that individuals with AHG or PTC deficiency have been reported to develop circulating anticoagulants following transfusion. The finding of an inhibitor of PTA in a known case of PTA deficiency was therefore predictable. Our lack of knowledge of the patient's status prior to transfusion does not allow us to state with certainty that we are dealing with an acquired form of circulating anticoagulant. We have been unable to obtain other known PTA deficient members of this patient's family for similar studies. Experience with the resistant state in PTC or AHG deficiency would lead us to conclude that most likely this is an acquired circulating anticoagulant.

It is of interest that the patient's serum did not possess any anticoagulant activity. No reason is known for this; one can only speculate that the anticoagulant is either inactivated, or used up during the coagulation process. (It is possible that treatment of the serum with $\mathrm{BaSO}_{4}$ might have brought out the activity of the anticoagulant; however, we have been unable to have the patient return for these studies.)

A heparin-like anticoagulant is ruled out on the basis of a normal protamine titration test and because no abnormalities of the plasma prothrombin time were ever elicited.

Of major interest in this study is the demonstration of a circulating anticoagulant by the use of an incubation technique in the thromboplastin generation test. Bergna and Pavlovsky (7) have shown that small amounts of time may elapse before an inhibitory effect of a circulating anticoagulant can be detected using the plasma recalcification time. No effect on recalcification time was demonstrable after four hours of incubation of reagent from our patient. The more sensitive thromboplastin generation test gave substantial evidence of an inhibitory effect of our patient's plasma after four hours of incubation of mixtures of patient's absorbed plasma with either normal sera or plasma.

The patient was reexamined one year after the initial study and the PTA inhibitor was still demonstrable.

\section{SUMMARY}

The demonstration of a circulating anticoagulant in PTA deficiency is described for the first time.

The anticoagulant could only be demonstrated by the use of the thromboplastin generation test after incubation of the patient's plasma with either normal sera or plasma.

The anticoagulant activity is confined to the patient's plasma. 


\section{REFERENCES}

1. Lawrence, J. S., and Johnson, J. B. The presence of a circulating anticoagulant in a male member of a hemophiliac family. Trans. Amer. clin. climat. Ass. 1941, 57, 223.

2. Margolius, A., Jr., and Ratnoff, O. D. A laboratory study of the carrier state in classic hemophilia. J. clin. Invest. 1956, 35, 1316.

3. Lewis, J. H., Ferguson, J. H., and Arends, T. Hemorrhagic disease with circulating inhibitors of blood clotting: Anti-AHF and anti-PTC in eight cases. Blood 1956, 11, 846.

4. Stefanini, M., and Dameshek, W. The Hemorrhagic Disorders. New York, Grune \& Stratton, 1955.

5. Richards, M. D., and Spaet, T. H. Immunization of rabbits against human antihemophilic factor (AHF). Blood 1956, 11, 473.

6. Lewis, J. H., and Didisheim, P. Production of antihuman PTC and anti-human proconvertin in rabbits. Proc. Soc. exp. Biol. (N. Y.) 1956, 93, 429.

7. Bergna, L. J., and Pavlovsky, A. Classification of hemophiliacs with development of an anticoagulant. Acta haemat. 1956, 16, 247.

8. Lisker, R., Josephson, A. M., Werbin, G., Shapiro, C. M., and Rozengvaig, S. The correction of a hemorrhagic diathesis in preparation for surgery: The correction of plasma thromboplastin antecedent deficiency. Arch. intern. Med. 1957, 100, 474.
9. Lee, R. I., and White, P. D. A clinical study of the coagulation time of blood. Amer. J. med. Sci. 1913, 145, 495.

10. Quick, A. J. The Hemorrhagic Diseases and the Physiology of Hemostasis. Springfield, Charles C Thomas, 1942.

11. Quick, A. J. The coagulation mechanism with specific reference to the interpretation of prothrombin time and a consideration of the prothrombin consumption time. Amer. J. clin. Path. 1949, 19, 1016.

12. Biggs, R., and Douglas, A. S. The thromboplastin generation test. J. clin. Path. 1953, 6, 23.

13. Ramot, B., and Singer, K. An unusual circulating anticoagulant in systemic lupus erythematosus. Acta haemat. 1956, 16, 158.

14. Allen, J. G., Moulder, P. V., Elghammer, R. M., Grossman, B. J., McKeen, C. L., Sanderson, M., Egner, W., and Crosbie, J. M. A protamine titration as an indication of a clotting defect in certain hemorrhagic states. J. Lab. clin. Med. 1949, 34, 473.

15. Ramot, B., Angelopoulos, B., and Singer, K. Plasma thromboplastin antecedent deficiency. Arch. intern. Med. 1955, 95, 705.

16. Rosenthal, R. L. Properties of plasma thromboplastin antecedent (PTA) in relation to blood coagulation J. Lab. clin. Med. 1955, 45, 123.

\section{ANNOUNCEMENTS OF MEETINGS}

The Fiftieth Annual Meeting of THE AMERICAN SOCIETY FOR CLINICAL INVESTIGATION will be held in Atlantic City, N. J., on Monday, May 5, 1958, at 9:00 A.M. at the Casino Theater on the Steel Pier.

The Fifteenth Annual Meeting of THE AMERICAN FEDERATION FOR CLINICAL RESEARCH will be held in Atlantic City. N. J., at the Casino Theater on the Steel Pier on Sunday, May 4, 1958, at 9:00 A.M.

THE ASSOCIATION OF AMERICAN PHYSICIANS will hold their Seventy-First Annual Meeting in Atlantic City, N. J., at the Casino Theater on the Steel Pier on Tuesday, May 6, 1958, at 9:30 A.M. and in the Vernon Room, Chalfonte-Haddon Hall on Wednesday, May 7, 1958, at 9:30 A.M. 